\title{
Composition and physicochemical properties of calcium silicate based sealers: A review article
}

\author{
Farnaz Jafari ${ }^{1}$, Sanaz Jafari ${ }^{2}$ \\ ${ }^{1}$ Assistant Professor, Department of Endodontics, Dental School, Tabriz Branch, Islamic Azad University, Tabriz, Iran \\ ${ }^{2}$ Assistant Professor, Orthodontics Department, Dentistry Faculty, Ilam University of Medical Sciences
}

Correspondence:

Orthodontics Department

Dentistry Faculty

Ilam University of Medical Sciences

00989143065611

dr.jafarif@gmail.com

Received: 04/06/2017

Accepted: 12/07/2017

Jafari F, Jafari S. Composition and physicochemical properties of calcium silicate based sealers: A review article. J Clin Exp Dent. 2017;9(10):e1249-55.

http://www.medicinaoral.com/odo/volumenes/v9i10/jcedv9i10p1249.pdf

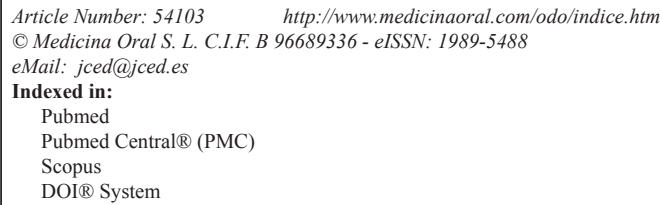

\begin{abstract}
Background: Recently a new generation of endodontic sealers has been developed based on calcium silicate as MTA Fillapex, Endoseal MTA, Total Fill BC Sealer, EndoSequence BC Sealer, iRoot SP, Endo CPM sealer, MTAAngelus and ProRoot Endo Sealer. A review of literature was conducted to discuss the composition, physicochemical properties, and clinical perspectives of calcium silicate based sealers.

Material and Methods: A literature search was conducted in PubMed and web of knowledge databases with appropriate MeSh terms and keywords. A total of 71 studies were reviewed for data extraction.

Results and Conclusions: Calcium silicate based sealers showed suitable physical properties to be used as an endodontic sealer. However, its high solubility remains an important issue. They show good performance regarding calcium ion release, film thickness, and fowability. More researches are required about features of calcium silicate based sealers before recommending them for clinical applications.
\end{abstract}

Key words: Calcium silicate, root canal filling materials, composition, physical properties.

\section{Introduction}

Endodontic sealers that recently have been developed are working as sealing agents in filling root canals (1). A variety of endodontic sealers is available including zinc oxide eugenol, calcium hydroxide, glass ionomer, silicone, resin, and bioceramic based sealers (2). Bioceramic based sealers are ceramic products that are designed particularly for medical and dental applications (3). These sealers include alumina, zirconia, bioactive glass, glass ceramics, hydroxyapatite, and calcium phosphates (4). Bioceramic based sealers are categorized into two groups of calcium silicate based sealers (Mineral Trioxide Aggregate (MTA) based and non MTA based) and calcium phosphate based sealers (2). Also, another categorization of bioceramic based sealers is available in two groups of bioactive and bioinert materials due to their interaction with the close, alive tissues (5). Bioactive materials, such as glass and calcium phosphate, interact with the surrounding tissue to encourage the growth of more durable tissues (6). The physicochemical properties of sealers have been always considered because of their biological and technical importance (2). 
Aiming at combining the physicochemical properties of a root canal sealer (7), a new generation of endodontic sealers has been produced based on calcium silicate as MTA Fillapex (8), EndosealMTA (9), Total Fill BC Sealer (10), EndoSequence BC Sealer (11), iRoot SP, Endo CPM sealer, MTA-Angelus and ProRoot Endo Sealer (12). Lack of an extensive review article on composition, physical properties and clinical perspectives of calcium silicate based sealers felt.

\section{Material and Methods}

The authors searched web of knowledge and PubMed databases, using the search terms of tricalcium silicate, root canal sealers, physical properties, material characterization, mineral trioxide aggregate (MTA), calcium silicate-based sealers, calcium release and solubility with different combinations. This initial search yielded 250 articles until October 2016, 179 of which were excluded due to not consistency to the topic and language other than English or Persian. The remaining 71 met our predefined criteria and were included in this review. Two researchers independently reviewed, extracted and summarized the data. Data extraction included composition, physicochemical properties and clinical perspectives of calcium silicate based sealers (13-33).

\section{Results}

\section{Composition}

Table 1 shows the manufacturer and composition of calcium silicate based sealers.

2. Physico-chemical properties

-Radioopacity

Radioopacity, a well-known characteristic of endodontic sealers, should exist in any root canal filling materials with a certain degree in order to evaluate the quality of root filling function (34). Two methods of standard discs and tissue simulator were used to evaluate radio opacity in one study which indicated that it was higher in AH Plus than MTA Fillapex and Endo CPM (34). Radioopacity of Endo CPM sealer was $6 \mathrm{mmAl}$ (35). Also, radiopacity of MTA Fillapex and AH-Plus were 3.9 and $18.4 \mathrm{mmAl}$ respectively (36). Xuereb (37), found the value of 10.8 and 4.3 for radioopacity of Endosequence BC and MTA Fillapex sealers. However, another study demonstrated the radioopacity of Endosequence $\mathrm{BC}$ sealer and $\mathrm{AH}$ Plus to be 3.84 and $6.90 \mathrm{~mm} \mathrm{Al}$ respectively (38). The radiopacity of Endoseal was lower than AH Plus (9).

-Setting time

The ANSI/ADA Specification number 2 requires that the setting time of a sealer shall be within $10 \%$ of that stated by the manufacturers (39). The final setting time was determined to be $85.66( \pm 6.03)$ minutes for Biodentine and $228.33( \pm 2.88)$ minutes for MTA (40). Endosequence $\mathrm{BC}$ Sealer required at least 168 hours to reach the final setting using the Gilmore needle method, and its micro- hardeness significantly declined when water was included in the sealer (41). Endosequence BC sealer and MTA Fillapex could not be set in dry condition within 3 days whereas they set in contact with the physiologic solution (HBSS) (37). The setting time values for EndoSequence BC Sealer and MTA Fillapex in moist conditions were 22.3 and 19.3 minutes respectively (37). These results are in contrast with another study, finding that the setting time of these materials is 2.7 hours (42). When there are minimal amounts of fluids in contact with the materials, dry conditions are not valid in vivo. An equivalent of 20 $\mathrm{cm}$ water pressure investigating the hydraulic conductance of dentin (43).

Dentin permeability is mainly caused by the dentinal tubules present. Permeability in dentin can be reduced by the apposition of tertiary dentin, the deposition of crystalline calcium phosphate, or the presence of the smear layer and coagulation products (37).

-Solubility

Solubility is the mass loss of a material during a period of immersion in water. The solubility of a sealer should not be superior to three percent by mass based on specification number 57 of ANSI/ADA (44). The solubility of both iRoot SP and MTA-Fillapex was high (20.64\% and $14.89 \%$, respectively), which are not fulfill ANSI/ADA requirements $(45,46)$. Amoroso-Silva (47) showed MTA Fillapex sealer possess a higher solubility and quantity of gaps in the dentin/ sealer interface when compared to the AH Plus sealer. Nevertheless, in another study, the solubility of MTA-Fillapex (48) and EndoSequence BC (42), were in line with ISO 6876/2001. MTA-Angelus also has low solubility (46) because of an insoluble matrix of crystalline silica within itself that preserve its integrity even in the presence of water (49). The solubility and water absorption increased significantly over time for both MTA Fillapex and AH Plus in 1 to 28 day period (48). MTA Fillapex had a higher solubility that guttaflow (50). MTA Fillapex and Endosequence BC sealers have a higher solubility than AH Plus (42). Solubility and disintegration of MTA Fillapex are lower than AH Plus (48). The solubility of AH Plus and MTA Angelus agreed with ANSI/ADA's requirements, whereas iRoot SP, MTA Fillapex, and Sealapex were unlike ANSI/ ADA's protocols (46). Morphological changes in both outer and inner surfaces after the solubility test were observed in SEM/EDX analysis of all sealers (46). Similar solubility, but a higher dimensional change of Endoseal was observed between Endoseal and AH Plus (9).

-Calcium release

For calcium ion release test, mostly, high release of calcium was indicated in the sealers in three hours assessment and by decreasing values over time (51). In contrast to AH Plus, iRoot SP, MTA Fillapex sealers showed high levels of $\mathrm{Ca}(2+)$ ion release (46).

Calcium release of MTA Fillapex was superior than 
Table 1: Composition of calcium silicate based sealers.

\begin{tabular}{|c|c|c|c|}
\hline Sealer & Manufacturer & Sealer contents & Some properties \\
\hline Total Fill BC Sealer (13) & $\begin{array}{l}\text { FKG Dentaire, La-Chaux-de-Fonds, } \\
\text { Switzerland }\end{array}$ & $\begin{array}{l}\text { premixed single syringe which } \\
\text { contains calcium silicates, calcium } \\
\text { phosphate monobasic, zirconium } \\
\text { oxide, tantalum oxide and thickening } \\
\text { agents }\end{array}$ & \\
\hline iRoot SP (14-15) & $\begin{array}{l}\text { Innovative BioCeramix Inc., } \\
\text { Vancouver,Canada }\end{array}$ & $\begin{array}{l}\text { calcium silicate, calcium phosphate, } \\
\text { calcium hydroxide, niobium oxide } \\
\text { and zirconium oxide }\end{array}$ & $\begin{array}{l}\text { insoluble, radiopaque, } \\
\text { aluminum free, hydrophilic, } \\
\text { ready to use calcium silicate } \\
\text { and resin based material } \\
\text { developed for permanent root } \\
\text { canal filling (15) }\end{array}$ \\
\hline $\begin{array}{l}\text { Ortho MTA (14) } \\
\text { OrthoMTA-PBS paste } \\
\text { (OrthoMTA mixed with } \\
\text { phosphate-buffered saline) is a } \\
\text { root canal obturation material } \\
(17) .\end{array}$ & - & $\begin{array}{l}\text { Powder (Tricalcium silicate, } \\
\text { dicalcium silicate, tricalcium } \\
\text { aluminate, tetracalciumalumino } \\
\text { ferrite, free calcium oxide, bismuth } \\
\text { oxide) and Liquid (deionized water) }\end{array}$ & \\
\hline DiaRootBioaggregate (18) & $\begin{array}{l}\text { DiaDent Group International, } \\
\text { Burnaby, BC, Canada }\end{array}$ & $\begin{array}{l}\text { Tricalcium silicate, dicalciumsilicate, } \\
\text { tantalum pentoxide, calcium } \\
\text { phosphate monobasic, amorphous } \\
\text { silicon oxide }\end{array}$ & $\begin{array}{l}\text { is considered as a modified } \\
\text { version of MTA, with the } \\
\text { advantage of being aluminum } \\
\text { free in composition }\end{array}$ \\
\hline EndoSeal (19-20) & EndoSeal, Maruchi, Seoul, Korea & $\begin{array}{l}\text { Sodium oxide, calcium oxide, } \\
\text { potassium oxide, magnesium oxide, } \\
\text { iron oxide, aluminium oxide, } \\
\text { titanium dioxide, zirconium oxide, } \\
\text { silicone dioxide }\end{array}$ & $\begin{array}{l}\text { Bismuth oxide is replaced with } \\
\text { zirconium oxide as the } \\
\text { radiopacifier in EndoSeal }\end{array}$ \\
\hline Endo-CPM (21) & Egeo, Buenos Aires, Argentina & $\begin{array}{l}\text { the same composition of MTA, } \\
\text { except for the addition of barium } \\
\text { sulfate and calcium chloride }\end{array}$ & $\begin{array}{l}\text { a sealer in two forms of powder } \\
\text { or liquid }\end{array}$ \\
\hline MTA Plus (22) & - & $\begin{array}{l}\text { a recent Hydraulic Calcium Silicate } \\
\text { Cement mixed with a polymer gel } \\
\text { and proposed as an endodontic sealer }\end{array}$ & $\begin{array}{l}\text { Has improved reactivity and a } \\
\text { prolonged ability to release } \\
\text { calcium }\end{array}$ \\
\hline MTA Fillapex $(15,23-28)$ & Angelus, Londrina, PR, Brazil & $\begin{array}{l}\text { natural resin, salicylate resin, diluting } \\
\text { resin, bismuth trioxide, } \\
\text { nanoparticulated silica, pigments and } \\
\text { MTA }\end{array}$ & $\begin{array}{l}\text { is a paste-catalyst MTA } \\
\text { containing resin based } \\
\text { bioceramic sealer which is } \\
\text { developed as a paste or paste } \\
\text { sealer (23) in a formulation that } \\
\text { allows its appropriate insertion } \\
\text { into the root canal as a } \\
\text { conventional endodontic sealer }\end{array}$ \\
\hline $\begin{array}{l}\text { Endosequence BC sealer }(15, \\
30,31)\end{array}$ & $\begin{array}{l}\text { Brasseler USA, Savannah, GA, } \\
\text { USA }\end{array}$ & $\begin{array}{l}\text { (injectable form) a premixed calcium } \\
\text { phosphate silicate-based sealer }\end{array}$ & $\begin{array}{l}\text { needs natural canal moisture for } \\
\text { setting reaction (26) }\end{array}$ \\
\hline NeoMTAPlus (33) & Avalon Biomed & \multirow[t]{2}{*}{ powder and a water-based gel } & \multirow{2}{*}{$\begin{array}{l}\text { When the powder to gel ratio is } \\
\text { low, a sealer type consistency is } \\
\text { obtained for these two materials }\end{array}$} \\
\hline QuickSet2 (33) & Avalon Biomed, Bradenton, FL & & \\
\hline ProRoot Endo Sealer (12) & $\begin{array}{l}\text { DENTSPLY Tulsa Dental } \\
\text { Specialties }\end{array}$ & $\begin{array}{l}\text { calcium sulphate, dicalcium silicate, } \\
\text { tricalcium silicate, bismuth oxide, } \\
\text { and a bit of tricalcium aluminate } \\
\text { Liquid } \\
\text { (viscous aqueous solution of a water } \\
\text { soluble polymer) }\end{array}$ & \\
\hline
\end{tabular}

guttaflow (50) and inferior than iRoot SP (52). EndoSequence BC Sealer had high tendency to release calcium ions than $\mathrm{AH}$ plus sealer (38). The highest leaching of calcium ion was exhibited by EndoSequence BC Sealer followed by MTA Fillapex (37). Phosphorus was leached in solution in higher quantities in EndoSequence BC Sealer compared with MTA Fillapex, which exhibited a negative value, indicating that there was the uptake of phosphorus from the solution rather than leaching (37). $-\mathrm{pH}$, alkalinizing activity and correlation with antibacterial properties

Zhang et al. (53) tested the antibacterial activity of iRoot SP sealer in vitro against $E$. faecalis found that iRoot SP showed a $\mathrm{pH}$ value of 11.5 even after setting, but its anti- 
bacterial effect was greatly diminished after seven days. EndoSequence BC Sealer has also been shown to have high $\mathrm{pH}(>11)$ (38). iRoot SP showed more $\mathrm{pH}$ value than MTA Fillapex (52).

The $\mathrm{pH}$ value of the Endo CPM was higher than that of MTA Fillapex $(>11)$; however, the bacterial inhibition zone produced by MTA Fillapex was greater than that produced by Endo CPM (54). Antibacterial activity of MTA Fillapex was related to the existence of resin as the main factor (54). However, the ability to maintain antibacterial activity after setting even with their primary high $\mathrm{pH}$ was observed in any of the sealers (54). The value of $\mathrm{pH}$ was slightly higher for MTA-Angelus than ProRoot (55).

MTA Fillapex has higher alkalinity and $\mathrm{pH}$ than AH Plus $(36,56)$ and higher alkalinizing activity than guttaflow (50). MTA Fillapex sealer had the lowest $\mathrm{pH}$ at 3 and 24 hours approximately 7.5 and increasing $\mathrm{PH}$ values over time (51). Higher alkalinity, was observed in Endoseal when compared to AH Plus (9). EndoSequence BC Sealer $\mathrm{pH}$ values greater than $\mathrm{AH}$ Plus sealer (38).

Dudeja stated that initial dressing of calcium hydroxide followed by obturation with Gutta-percha and iRootSP and MTA Fillapex sealers may be considered as an alternative treatment modality for inflammatory resorption and it is beneficial when compared to the long-term calcium hydroxide application (52). The reason for this phenomenon is calcium ion release performed by bioceramic sealers.

Also, MTA based sealer demonstrate higher PH values than resin based sealers, MTA, calcium enriched mixture (CEM) cement, and Portland cement generated more alkalinity and the $\mathrm{pH}$ of 9.47-10.80 (57).

-Flowability, film thickness and dimensional stability Flow determines the ability of sealers for filling the irregularities, and it is the viscosity that determines the flow characteristics (58). According to ISO 6786/2001, a root canal sealer should have a flow rate of not less than $20 \mathrm{~mm}$ (12). MTA Fillapex had flowability higher than $20 \mathrm{~mm}$ and a film thickness lower than $50 \mu \mathrm{m}$ (51). MTA Fillapex was significantly more flowable than AH Plus by the results of Zhou H et al. (42) and Silva EJ et al. (56). Others stated similar flow, film thickness and inferior compressive strength of MTA Fillapex when compared to AH Plus sealers (45). Flow of Endoseal was higher than AH Plus (9). Also, they were a similarity between MTA Fillapex and Endosequence BC sealers (42). Film thickness of MTA Fillapex is higher than both AH Plus and Endosequence BC sealer (42).

Endosequence BC Sealer (38) showed flow according to ISO 6876/2001 recommendations. The flow test revealed that BC Sealer and AH Plus presented flow of 26.96 $\mathrm{mm}$ and $21.17 \mathrm{~mm}$ respectively (38).

3. An Introduction to X-Ray Diffraction, Elemental microanalysis, and micromorphology techniques

To investigate most crystalline products in a cement sample, X-ray diffraction is used as an efficient method to study cement structures (59). Different items such as interspersed granules with approximate 1-3 $\mu \mathrm{m}$ wide, and $\mathrm{C}$ (from salicylate and natural resins), $\mathrm{O}, \mathrm{Si}, \mathrm{Al}$ (4.93 wt $\%), \mathrm{S}, \mathrm{Ca}(5.37 \mathrm{wt} \%$ ) and $\mathrm{Cl}$ (all from calcium silicate component, which is MTA), Ti (from pigments), and $\mathrm{Bi}$ (from radiopacifier) were displayed in a uniform surface of Freshly mixed MTA Fillapex. It is mention worthy that EDX showed a reduction in level of the constitutive elements like Si (1.11 wt\%), Ti (1.19 wt\%) and the disappearance of S and Bi following soaking in HBSS. Moreover, the sharp enhancement of $\mathrm{Ca}(20.18 \mathrm{wt} \%)$ and the appearance of $\mathrm{P}(13.04 \mathrm{wt} \%)$ and elements from HBSS was also observed. Globular precipitates in the size of $2-8 \mu \mathrm{m}$ wide were used in order to cover the surface area. Besides, the agglomerates were with uncoated zones and the matrix was particular with the following characteristics:

The ratio of $\mathrm{Ca} / \mathrm{P}$ for the whole picture area whether coated or uncoated zones was 1.2. More investigations revealed a non-homogeneous potential for nucleating $\mathrm{Ca}$ poor non apatitic calcium phosphates for this substance (50). After immersing the mentioned MTA Fillapex sealer in HBSS, it was observed that porous matrix is interspersed with cement and bismuth-rich particles. The presence of Tricalcium silicate as well as bismuth oxide and silicon oxide was proven by XRD analyses. No hydration was found on particles of cement. Moreover, XRD analyses did not show any calcium hydroxide peak (37).

In the following, a highly dense matrix which had the lowest porosity was shown by the set EndoSequence BC Sealer (37) immersed in HBSS. The particles of cement were used to intersperse rich-zirconium particles (with a composition based on calcium and silicon elements). Moreover, the rectangular-shaped particles which were rich in phosphor and calcium were found. Some peaks were detected through phase analysis for materials such as tricalcium silicate, calcium phosphate, zirconium oxide, and calcium hydroxide. iRoot SP, and MTA Fillapex sealers proved high levels of calcium and carbon on the contrary to AH Plus when they were evaluated with calcium and carbon (46).

The compact and generally homogeneous external surfaces of iRoot SP with some porosities were proven by Borges (46). For iRoot SP, O, Ca, Zr, C and Si peaks were shown through carrying out an EDX analysis of the area in a decreasing order. Accordingly; MTA Fillapex showed a surface mostly compact and homogeneous, when EDX, in decreasing order, exhibited $\mathrm{C}, \mathrm{Zr}, \mathrm{O}, \mathrm{W}$, $\mathrm{Ca}$ and Si peaks.

4. Effect of material composition on physicochemical properties

New generation calcium silicate based sealers: Endosequence $\mathrm{BC}$ sealer use pure tricalcium silicate to avoid 
the aluminate phase and also any heavy metal inclusions that are synonymous with the use of Portland cement (60).

Radioopacifiers: The radiopacifier particle size had limited effect on the sealer microstructure and chemical properties (36). However, the use of barium zirconate as radiopacifier further intensified the release of calcium hydroxide compared with those using zirconiumoxide (60). Calcium phosphate was also deposited on the material surface in the light-curable resin modified materials when barium zirconate was used as radiopacifier (60). The materials that used barium zirconate as radiopacifier exhibited leaching of barium in solution, particularly the water based materials (60). The clinical implications of barium leaching from dental materials need to be investigated further.

Resin: Although there was no evidence of hydration in the light-curable resins like Bis-GMA/TEGDMA, calcium hydroxide was leached in solution (60).

\section{Conclusions}

Composition: When concerning the composition of MTA-based sealers, iRoot SP, DiaRoot Bioaggregate and Endosequence BC sealer are aluminate free calcium silicate based sealers. However, OrthoMTA, EndoSeal, EndoCPM, MTA Plus and ProRoot endo sealer contains it. The presence of aluminium compounds is a principal disadvantage of Portland Cement derived materials, because of calcium sulfate aluminates which release aluminium ions into biologic systems (61). Aluminium is toxic to osteoblasts and inhibits bone mineralization. It also induces renal dystrophy, dementia, Alzheimer and toxic effect on red blood cells, parathyroid glands and chromosomes $(62,63)$.

Radioopacifiers suitable for dental applications include barium sulfate, zirconium oxide, bismuth oxide, tantalum oxide and mixtures of them. Radioopacifier for Endoseal and iRootSP is zirconium oxide, while for OrthoMTA and ProRoot endo sealer is bismuth oxide and radoopacifying agent for EndoCPM is barium sulfate.

The effects of bismuth oxide concentration in the biological and physicochemical properties of MTA have been questioned (64-66). Previous studies have demonstrated interferences with cell viability and growth $(65,67)$, with the hydration mechanisms of MTA (68) and negative effects on the compressive strength of the cement (69). Another problem is discoloration of bismuth oxide containing sealers in contact with sodium hypochlorite (70).

Radioopacity: The results of radioopacity of different MTA-based sealers showed their lower radioopacity in comparison with famous resin based sealers. However, it is not an important issue because of application of sealers together with gutta-percha. The radioopacity value of selears from the most to least value is as the following: AH Plus, Endosequence BC, Endo CPM and MTA Fillapex.

Setting time: There was limited data for setting time of MTA-Based sealers. Taking together the data for different databases, it is important to simulate $20 \mathrm{~cm} \mathrm{H} 2 \mathrm{O}$ hydraulic pressure of dentine for evaluating setting time of sealers. When assessing their criteria, both Endosequence BC and MRA Fillapex showed acceptable setting time. However, in the dry condition setting time values for them in high and not acceptable.

Solubility: Thorough screening of results of articles on the solubility of MTA-based sealers it can be concluded that most of the sealers of this type show high solubility and dimensional and structural change after immersion in water when comparing with the standard resin based sealers. So, clinical application of them should be conducted with caution, especially in open apex teeth.

Calcium ion release: $\mathrm{Ca}$ ion release in iRootSP and Endosequence $\mathrm{BC}$ is more than MTA Fillapex and in MTA Fillapex is more than AH Plus sealer.

PH and alkalinity: Overall alkalinity of tested calcium silicate based sealers are more than AH Plus. The most $\mathrm{PH}$ value was observed for iRootSP, EndoCPM and EEndosequence BC sealer followed by MTA Fillapex and EndoSeal.

Flow: Overall flowability of tested calcium silicate based sealers are more than AH Plus. The value is similar between MTA Fillapex, Endosequence BC, and EndoSeal

XRD: MTA Fillapex sealer uptakes phosphorus and carbon from tissue fluids. The set in contact with tissue fluid form is porous and does not contain calcium hydroxide peak in XRD. While set Endosequence BC in contact with tissue fluid is dense and rich for calcium phosphate and calcium hydroxide. iRootSP contains homogeneous surface with low porosity, which contains calcium and oxygen as the main component. However, main component for set in tissue fluid MTA Fillapex is calcium and phosphorus.

Calcium silicate based sealers showed suitable physical properties to be used as an endodontic sealer. However, its high solubility remains an important issue. Resin based sealers show better performance in radioopacity, although calcium ion release, film thickness and fowability of calcium silicate based sealers were better. Further studies in different settings about other physico-chemical features of calcium silicate based sealers are needed before recommending them for clinical applications.

\section{References}

1. Kopper P, Fiqueiredo J, Della Bona A, Vanni J, Bier C, Bopp S. Comparative in vivo analysis of the sealing ability of three endodontic sealers in post-prepared root canals. International Endodontic Journal. 2003;36(12):857-63.

2. A AL-H, Che Ab Aziz ZA. Bioceramic-Based Root Canal Sealers: A Review. International Journal of Biomaterials. 2016;2016.

3. Shokouhinejad N, Gorjestani H, Nasseh A, Hoseini A, Mahmoudi 
M, Shamshiri A. Push-out bond strength of gutta-percha with a new bioceramic sealer in the presence or absence of smear layer. Australian Endodontic Journal. 2011;39(3):102-6.

4. Hench LL. Bioceramics: from concept to clinic. Journal of the American Ceramic Society. 1991;74(7):1487-510.

5. Best S, Porter A, Thian E, Huang J. Bioceramics: past, present and for the future. Journal of the European Ceramic Society. 2008;28(7):1319-27.

6. Koch K, Brave D. A new day has dawned: the increased use of bioceramics in endodontics. Dentaltown. 2009;10(4):39-43.

7. Vitti RP, Prati C, Sinhoreti MA, Zanchi CH, Souza ESMG, Ogliari FA, et al. Chemical-physical properties of experimental root canal sealers based on butyl ethylene glycol disalicylate and MTA. Dental materials : official publication of the Academy of Dental Materials. 2013;29(12):1287-94

8. Mestieri LB, Gomes-Cornelio AL, Rodrigues EM, Salles LP, Bosso-Martelo R, Guerreiro-Tanomaru JM, et al. Biocompatibility and bioactivity of calcium silicate-based endodontic sealers in human dental pulp cells. Journal of applied oral science : revista FOB. 2015;23(5):467-71.

9. Lim ES, Park YB, Kwon YS, Shon WJ, Lee KW, Min KS. Physical properties and biocompatibility of an injectable calcium-silicatebased root canal sealer: in vitro and in vivo study. BMC oral health. 2015;15(1):129.

10. Rodriguez-Lozano FJ, Garcia-Bernal D, Onate-Sanchez RE, Ortolani-Seltenerich PS, Forner L, Moraleda JM. Evaluation of cytocompatibility of calcium silicate-based endodontic sealers and their effects on the biological responses of mesenchymal dental stem cells. International endodontic journal. 2015.

11. Deniz Sungur D, Moinzadeh AT, Wesselink PR, Calt Tarhan S, Ozok AR. Sealing efficacy of a single-cone root filling after post space preparation. Clinical oral investigations. 2016;20(5):1071-7.

12. Al-Haddad A, Che Ab Aziz ZA. Bioceramic-Based Root Canal Sealers: A Review. International Journal of Biomaterials. 2016;2016:9753210

13. Carvalho NK, Prado MC, Senna PM, Neves AA, Souza EM, Fidel SR, et al. Do smear-layer removal agents affect the push-out bond strength of calcium-silicate based endodontic sealers? International endodontic journal. 2016.

14. Prati C, Gandolfi MG. Calcium silicate bioactive cements: Biological perspectives and clinical applications. Dental materials : official publication of the Academy of Dental Materials. 2015;31(4):351-70.

15. Jafari F, Jafari S. Importance and methodologies of endodontic microleakage studies: A systematic review. Journal of clinical and experimental dentistry. 2017;9(6):e812-e9.

16. Zhang W, Li Z, Peng B. Assessment of a new root canal sealer's apical sealing ability. Oral surgery, oral medicine, oral pathology, oral radiology, and endodontics. 2009;107(6):e79-82.

17. Yoo JS, Chang SW, Oh SR, Perinpanayagam H, Lim SM, Yoo $\mathrm{YJ}$, et al. Bacterial entombment by intratubular mineralization following orthograde mineral trioxide aggregate obturation: a scanning electron microscopy study. International journal of oral science. 2014;6(4):227-32.

18. Bosio CC, Felippe GS, Bortoluzzi EA, Felippe MC, Felippe WT, Rivero ER. Subcutaneous connective tissue reactions to iRoot SP, mineral trioxide aggregate (MTA) Fillapex, DiaRoot BioAggregate and MTA. International endodontic journal. 2014;47(7):667-74.

19. Yoo YJ, Baek SH, Kum KY, Shon WJ, Woo KM, Lee W. Dynamic intratubular biomineralization following root canal obturation with pozzolan-based mineral trioxide aggregate sealer cement. Scanning. 2016;38(1):50-6.

20. Kim RJ, Shin JH. Cytotoxicity of a novel mineral trioxide aggregate-based root canal sealer [corrected]. Dental materials journal. 2014:33(3):313-8.

21. Assmann E, Scarparo RK, Bottcher DE, Grecca FS. Dentin bond strength of two mineral trioxide aggregate-based and one epoxy resin-based sealers. Journal of endodontics. 2012;38(2):219-21.

22. Gandolfi MG, Siboni F, Primus CM, Prati C. Ion release, porosity, solubility, and bioactivity of MTA Plus tricalcium silicate. Jour- nal of endodontics. 2014;40(10):1632-7.

23. Yoshino P, Nishiyama CK, Modena KC, Santos CF, Sipert CR. In vitro cytotoxicity of white MTA, MTA Fillapex(R) and Portland cement on human periodontal ligament fibroblasts. Brazilian dental journal. 2013;24(2):111-6.

24. Jafari F, Aghazadeh M, Jafari S, Khaki F, Kabiri F. In vitro Cytotoxicity Comparison of MTA Fillapex, AH-26 and Apatite Root Canal Sealer at Different Setting Times. Iranian endodontic journal. 2017;12(2):162-7.

25. Jafari F, Jafari S, Samadi Kafil H, Momeni T, Jamloo H. Antifungal Activity of Two Root Canal Sealers against Different Strains of Candida. Iranian endodontic journal. 2017;12(1):98-102.

26. Jafari F, Rahimi S, Shahi S, Jafari S. Endodontic microleakage studies: correlation among different methods, clinical relevance, and potential laboratory errors. Minerva stomatologica. 2017;66(4):16977.

27. Jafari F, Samadi Kafil H, Jafari S, Aghazadeh M, Momeni T. Antibacterial Activity of MTA Fillapex and AH 26 Root Canal Sealers at Different Time Intervals. Iranian endodontic journal. 2016;11(3):192-7.

28. Jafari F, Sobhani E, Samadi-Kafil H, Pirzadeh A, Jafari S. In vitro evaluation of the sealing ability of three newly developed root canal sealers: A bacterial microleakage study. Journal of clinical and experimental dentistry. 2016;8(5):e561-e5.

29. Jafari F, Kafil HS, Jafari S, Aghazadeh M, Momeni T. Antibacterial Activity of MTA Fillapex and AH 26 Root Canal Sealers at Different Time Intervals. Iranian endodontic journal. 2016;11(3):192-7. 30. Han L, Okiji T. Bioactivity evaluation of three calcium silicate-based endodontic materials. International endodontic journal. 2013;46(9):808-14

31. Loushine BA, Bryan TE, Looney SW, Gillen BM, Loushine RJ, Weller RN, et al. Setting properties and cytotoxicity evaluation of a premixed bioceramic root canal sealer. Journal of endodontics. 2011;37(5):673-7.

32. Koch K, Brave D. Bioceramic technology-the game changer in endodontics. Endodontic Practice US. 2009;12:7-11.

33. McMichael GE, Primus CM, Opperman LA. Dentinal Tubule Penetration of Tricalcium Silicate Sealers. Journal of endodontics. 2016;42(4):632-6.

34. Malka V, Hochscheidt G, Larentis N, Grecca F, Fontanella V, Kopper P. A new in vitro method to evaluate radio-opacity of endodontic sealers. Dentomaxillofacial Radiology. 2015;44.

35. Guerreiro-Tanomaru JM, Duarte MA, Goncalves M, TanomaruFilho M. Radiopacity evaluation of root canal sealers containing calcium hydroxide and MTA. Brazilian oral research. 2009;23(2):11923.

36. Viapiana R, Guerreiro-Tanomaru JM, Hungaro-Duarte MA, Tanomaru-Filho M, Camilleri J. Chemical characterization and bioactivity of epoxy resin and Portland cement-based sealers with niobium and zirconium oxide radiopacifiers. Dental materials : official publication of the Academy of Dental Materials. 2014;30(9):1005-20.

37. Xuereb M, Vella P, Damidot D, Sammut CV, Camilleri J. In situ assessment of the setting of tricalcium silicate-based sealers using a dentin pressure model. Journal of endodontics. 2015;41(1):111-24.

38. Candeiro GT, Correia FC, Duarte MA, Ribeiro-Siqueira DC, Gavini G. Evaluation of radiopacity, $\mathrm{pH}$, release of calcium ions, and flow of a bioceramic root canal sealer. Journal of endodontics. 2012;38(6):842-5.

39. Marin-Buza G, Silva-Sousa Y, da Cunha S, Rached-Junior F, Bonetti-Filho I, Sousa-Neto M, et al. Physicochemical properties of endodontic sealers of different bases. Journal of Applied Oral Sciences. 2011;20(4):455-61.

40. Kauo M, Schafer E, Dammaschke T. An in vitro study of different material properties of Biodentine compared to ProRoot MTA. Head and Face Medicine. 2015;11(16).

41. Camilleri J, Mallia B. Evaluation of the dimensional changes of mineral trioxide aggregate sealer. International endodontic journal. 2011;44(5):416-24.

42. Zhou HM, Shen Y, Zheng W, Li L, Zheng YF, Haapasalo M. 
Physical properties of 5 root canal sealers. Journal of endodontics. 2013;39(10):1281-6.

43. Ozok AR, Wu MK, Wesselink PR. The effects of post-extraction time on the hydraulic conductance of human dentine in vitro. Archives of oral biology. 2002;47(1):41-6.

44. Association AD. ANSI/ADA Specification $n^{\circ}$ 57: Endodontic sealing material. Chicago: ADA. 2000.

45. Viapiana R, Flumignan DL, Guerreiro-Tanomaru JM, Camilleri J, Tanomaru-Filho M. Physicochemical and mechanical properties of zirconium oxide and niobium oxide modified Portland cement-based experimental endodontic sealers. International endodontic journal. 2014;47(5):437-48.

46. Borges RP, Sousa-Neto MD, Versiani MA, Rached-Junior FA, De-Deus G, Miranda CE, et al. Changes in the surface of four calcium silicate-containing endodontic materials and an epoxy resinbased sealer after a solubility test. International endodontic journal. 2012;45(5):419-28

47. Amoroso-Silva PA, Guimaraes BM, Marciano MA, Duarte MA, Cavenago BC, Ordinola-Zapata R, et al. Microscopic analysis of the quality of obturation and physical properties of MTA Fillapex. Microscopy research and technique. 2014;77(12):1031-6.

48. Vitti RP, Prati C, Silva EJ, Sinhoreti MA, Zanchi CH, de Souza e Silva MG, et al. Physical properties of MTA Fillapex sealer. Journal of endodontics. 2013;39(7):915-8

49. Fridland M, Rosado R. Mineral trioxide aggregate (MTA) solubility and porosity with different water-to-powder ratios. Journal of endodontics. 2003;29(12):814-7.

50. Gandolfi MG, Siboni F, Prati C. Properties of a novel polysiloxane-guttapercha calcium silicate-bioglass-containing root canal sealer. Dental materials : official publication of the Academy of Dental Materials. 2016;32(5):e113-26.

51. Marciano MA, Duarte MAH, Camilleri J. Calcium silicate-based sealers: Assessment of physicochemical properties, porosity and hydration. Dental Materials. 2016;32(2):e30-e40.

52. Dudeja C, Taneja S, Kumari M, Singh N. An in vitro comparison of effect on fracture strength, $\mathrm{pH}$ and calcium ion diffusion from various biomimetic materials when used for repair of simulated root resorption defects. Journal of conservative dentistry : JCD. 2015;18(4):279-83.

53. Zhang H, Shen Y, Ruse ND, Haapasalo M. Antibacterial activity of endodontic sealers by modified direct contact test against Enterococcus faecalis. Journal of endodontics. 2009;35(7):1051-5.

54. Morgental RD, Vier-Pelisser FV, Oliveira SD, Antunes FC, Cogo DM, Kopper PM. Antibacterial activity of two MTA-based root canal sealers. International endodontic journal. 2011;44(12):1128-33.

55. Duarte M, Demarchi A, Yamashita J, Kuga M, Fraga Sde C. pH and calcium ion release of 2 root-end filling materials. Oral Surgery, Oral Medicine, Oral Pathology, Oral Radiology and Endodontics. 2003;95(3):345-7.

56. Silva EJ, Rosa TP, Herrera DR, Jacinto RC, Gomes BP, Zaia AA. Evaluation of cytotoxicity and physicochemical properties of calcium silicate-based endodontic sealer MTA Fillapex. Journal of endodontics. 2013;39(2):274-7.

57. Ghazvini S, Tabrizi M, Kobarfard F, Baghban A, Asgary S. Ion release and $\mathrm{pH}$ of a new endodontic cement, MTA and Portland cement. Iranian Endodontic Journal. 2009;4(2):74-8.

58. Johnson P, Thomas B, Paulaian B, Emil Sam J, Raja J, James J. MTA BASED ROOT CANAL SEALERS-A CRITICAL REVIEW. Journal of the Indian Dental Association Tamil Nadu. 2014;5(6):30-4.

59. Islam I, Chng H, Yap A. X-ray diffraction analysis of mineral trioxide aggregate and Portland cement. International Endodontic Journal. 2006;39(3):220-5.

60. Camilleri J. Tricalcium silicate cements with resins and alternative radiopacifiers. Journal of endodontics. 2014;40(12):2030-5.

61. Fridland M, Rosado R. MTA solubility: a long term study. Journal of endodontics. 2005;31(5):376-9.

62. Savarino L, Cervellati M, Stea S, Cavedagna D, Donati M, Pizzoferrato A, et al. In vitro investigation of aluminum and fluoride relea- se from compomers, conventional and resin-modified glass-ionomer cements: a standardized approach. Journal of Biomaterials Science, Polymer Edition. 2000;11(3):289-300.

63. Rodriguez M, Felsenfeld AJ, Llach F. Aluminum administration in the rat separately affects the osteoblast and bone mineralization. Journal of Bone and Mineral Research. 1990;5(1):59-67.

64. Camilleri J. Evaluation of the physical properties of an endodontic Portland cement incorporating alternative radiopacifiers used as root-end filling material. International endodontic journal. 2010;43(3):231-40.

65. Camilleri J, Montesin FE, Papaioannou S, McDonald F, Pitt Ford TR. Biocompatibility of two commercial forms of mineral trioxide aggregate. International endodontic journal. 2004;37(10):699-704.

66. Cutajar A, Mallia B, Abela S, Camilleri J. Replacement of radiopacifier in mineral trioxide aggregate; characterization and determination of physical properties. Dental materials : official publication of the Academy of Dental Materials. 2011;27(9):879-91.

67. Min KS, Chang HS, Bae JM, Park SH, Hong CU, Kim EC. The induction of heme oxygenase-1 modulates bismuth oxide-induced cytotoxicity in human dental pulp cells. Journal of endodontics. 2007;33(11):1342-6.

68. Camilleri J. Hydration mechanisms of mineral trioxide aggregate. International endodontic journal. 2007;40(6):462-70.

69. Coomaraswamy KS, Lumley PJ, Hofmann MP. Effect of bismuth oxide radioopacifier content on the material properties of an endodontic Portland cement-based (MTA-like) system. Journal of endodontics. 2007;33(3):295-8.

70. Marciano MA, Duarte MA, Camilleri J. Dental discoloration caused by bismuth oxide in MTA in the presence of sodium hypochlorite. Clinical oral investigations. 2015;19(9):2201-9.

\section{Conflicts of Interest}

The authors have declared that no conflict of interest exist. 